\title{
Variability and Heritability of Yield and Yield Components of Various Rice (Oryza sativa L.) Varieties in Port Harcourt, Nigeria
}

\author{
Okoye $^{1}$, C. C., Dimkpa ${ }^{1}$, S. O. N., Efisue ${ }^{2}$ A. A., and Olawamide ${ }^{3}$ D. O. \\ 1. Department of Crop and Soil, River State University, P.M.B 5080, Port-Harcourt, \\ River State, Nigeria \\ 2. Department of Crop and Soil Science, Faculty of Agriculture, University of Port Harcourt, Rivers State, \\ Nigeria \\ 3. Department of Crop, Soil and Pest Management, Federal University of Technology Akure, Nigeria
}

\begin{abstract}
Authors' contributions
This work was carried out in collaboration among all the authors. Authors OCC, DSON and EAA designed the study. DSON further supervised the research while EAA supplied majority of the rice lines used for the study. Authors ODO performed the statistical analyses. Author OCC wrote the protocol, managed the literature searches and wrote the first draft of the manuscript. All authors read and approved the final manuscript.
\end{abstract}

\begin{abstract}
Field experiments were conducted at the Rivers State University Teaching and Research Farm Nkpolu, Port Harcourt, during the 2019 planting season under rainfed condition and complimented by irrigation in two different planting dates to access the genetic variability and heritability in yield and yield components of twenty-five rice varieties. The experiments were laid out in a randomized complete block design with three replications. Data were collected on eleven yield and yield components. Results from the analysis of variance indicated significant differences $(\mathrm{P} \leq 0.01 \leq 0.05)$ among the varieties for all parameters except plant height and tiller number in planting date one. Combined analysis of variance across planting dates showed that there was significant variation $(\mathrm{P} \leq$ 0.01 ) among the rice varieties for all parameters evaluated. The varietal mean performance for phenological parameters showed significant differences $(\mathrm{P} \leq 0.05)$ for all parameters except tiller number in planting date one. Variability evaluation of varieties for yield parameters showed significant differences $(\mathrm{P} \leq 0.05)$ for all parameters evaluated except for 100-grain weight in planting date two. The pooled mean values of the varieties differed significantly $(\mathrm{P} \leq 0.05)$ for all yield parameters evaluated. The highest grain yield per stand was recorded in UPIA 2 with $7.41 \mathrm{~g} / \mathrm{stand}$, and was significantly different from FARO 67 with the least $(1.70 \mathrm{~g} / \mathrm{stand})$. The estimate of variance components showed that phenotypic variance $(\mathrm{Vp})$ and phenotypic coefficient of variation $(\mathrm{PVC})$ were higher than their corresponding genotypic variance $(\mathrm{Vg})$ and genotypic coefficient of variation $(\mathrm{GCV})$ for all the parameters studied. Heritability estimates in broad sense were found to be moderate for majority of the parameters, except leaf area $(68.12 \%)$, panicle number $(63.41 \%)$, spikelet fertility $(50.23 \%)$ and grain yield per stand $(55.87 \%)$ that had high heritability estimates and tiller number $(15.93 \%)$ which had a low estimate. However, only leaf area, panicle number and grain yield per stand had high heritability estimates which were accompanied by high genetic advance. There was considerable variation among the 25 rice varieties evaluated. UPIA 2 and FARO 44 had the best agronomic performance. However, UPN 324, UPN 228, FARO 61 and 66 could be selected for onward improvement programme.
\end{abstract}

Keynote: Grain yield, heritability, Oryza sativa, variation, yield components

DOI: $10.7176 /$ ALST/86-04

Publication date:March $31^{\text {st }} 2021$

\section{Introduction}

Rice belongs to the genus Oryzae which contains about 20 diverse species including O. glaberrima, $O$. sativa, $O$. perennis, O.nivara, etc. (Efisue et al., 2008). Rice consumption and production has grown in popularity over the years (Kumar et al., 2017), and has become one of the most important grain of the gramineae family in Nigeria, such that it can be considered as both cash (FAO, 2004) and food security crop (Oluwaseyi et al., 2016, Balqees et al., 2019).

Rice varietal improvement has come a long way in Nigeria over the past decades with evidences of success in the development of early maturing varieties having higher grain yield, better grain quality, high milling recovery and nutrient content much more than what was obtained in the local unimproved varieties, as is evident in the improved FARO lines (Oluwaseyi et al., 2016). These improvement programs are always targeted towards an area of need in a particular environment or to tackle a prevailing problem in a crop of interest. In spite of the strides achieved so far in rice breeding, further and speedy improvement of rice varieties in Nigeria are imperative but have been hampered by a number of constraints and several factors militating against rice production/processing such as low yielding varieties, late maturing varieties, among other factors (Oluwaseyi et al., 2016, Dimkpa, 2014). 
Therefore, the need to develop varieties that address the major constraints to rice production is of paramount importance (Truong et al., 2018, Dimkpa et al., 2015). In as much as we have a lot of improved varieties, there is also the need to evaluate the landraces and select for those traits that made them survivors in our environment and to collate germplasm suitable for peculiar agroecological zone for onward breeding programme because the improved varieties are not holistic in terms of all-important traits.

In view of the growing population, the basic objective of the plant breeders would always be towards yield improvement in staple food crops (Kahani \& Hittalmani, 2016, Mukesh et al., 2018). Yield and yield attributing parameters are the most widely targeted traits for rice improvement programmes in the world (Mukesh et al., 2018). Grain yield is a quantitative trait, resulting from the interaction of many variables (Singh et al., 2017). Variability is the centrepiece of plant breeding (Ubi et al., 2011). In planning and executing any breeding programme for improvement on quantitative traits, evaluation of genetic variability available in crop species is the first step to select better performing lines among divergent groups and thereafter, quantify the extent of variability in the trait(s) of interest (Kahani \& Hittalmani, 2016). Therefore, success of plant breeding activities entirely depends on the existence of genetic variability with respect to desired traits in the plant population to enhance the adoption of appropriate breeding strategies for the utilization of their inherent potential (Efisue et al., 2009; Adhikari et al., 2018). Information on genetic variances and their effects have contributed to rice improvement and to the understanding of gene action involved in the expression of heterosis and economically important quantitative traits (Efisue et al., 2009).

The knowledge of heritability of a trait is important because it determines the extent to which plant improvement through selection is possible (Efisue et al., 2009). It is not enough to have desirable trait(s) in a particular crop, but the stability of such traits such that they can be transferred from parents to progenies determines the success of any breeding programme. Heritability and genetic advance assist breeders to decide and select superior plants that can perform superior for the traits of interest in subsequent generations (Kahani \& Hittalmani, 2016). Heritability estimates along with genetic advance is more precise in predicting the genetic gain under selection than heritability alone.

Variability, genetic diversity, expected genetic advance and heritability of the traits are therefore the basis of genetic improvement of traits of economic importance such as grain yield. The objectives of this study were therefore, to evaluate the yield and yield components of twenty-five rice varieties and assess the magnitude of genetic variability existing among them and to determine the heritability and genetic advance of the yield traits.

\section{Materials and Methods}

The experimental was carried out at the Rivers State University Teaching and Research Farm Nkpolu, Port Harcourt $\left(4^{0} 46^{1} \mathrm{~N}, 7^{0} 10^{1} \mathrm{E}\right)$ during the 2019 planting season under rainfed condition complimented by irrigation. Twenty-five rice varieties were used for this study These comprised of seventeen (17) anther cultured Korean rice lines (UPN) collected from the University of Port Harcourt Rice Germplasm, seven (7) improved rice varieties and one (1) Ebonyi landrace (Okporogwu) collected from Ebonyi State University Research Farm, Abakaliki, Ebonyi State (Table 1). The experiment was set up in plastic bags containing top soil mixed with pure sand in the ratio of 2:1 that was collected from the school farm, the bags were laid out in a randomized complete block design with three replications. There were two planting dates for the twenty-five (25) rice varieties, the early (June) and late (August). Each variety was planted in a $2650 \mathrm{~cm}^{3}$ volume nursery bag and transplanted into a bigger bag of $6283 \mathrm{~cm}^{3}$ volume after 4 weeks for increased surface area for the root development. NPK (15:15:15) was applied as a basal application of $200 \mathrm{~kg} \mathrm{ha}^{-1}$. Weeding was done by hand pulling on sight. The plants were irrigated equally in the absence of rainfall. The plants were shaded with palm frond from excessive sunlight and rainfall until transplanting. Three weeks after transplanting, Urea was applied at the rate of $65 \mathrm{~kg} \mathrm{ha}^{-1}$ (converted to the volume of the container) and the second rate of $35 \mathrm{~kg} \mathrm{ha}^{-1}$ (converted to the volume of the container) was applied at the beginning of booting stage. The agronomic characters were measured at weekly intervals. The 'Standard Evaluation System (SES) for Rice' reference manual (IRRI, 2002) was used for all trait measurements. Measured characters include: plant height - was recorded using meter rule $(\mathrm{cm})$, measured from the soil surface to the tip of the tallest leaf; flag leaf - the length and width of the flag leaf were measured using meter rule and leaf area $\left(\mathrm{cm}^{2}\right)$ calculated from the values of the length and width, days to $50 \%$ flowering - recorded for all varieties from seeding date to the day when $50 \%$ flowered; tiller numbers were calculated per stand for each variety, panicle parameters - two randomly sampled panicles per variety were used for data recording for panicle traits at maturity and it includes panicle length, which was measured using meter rule, number of panicle, done by counting the panicles per stand, panicle weight, measured using an electronic balance and spikelet fertility which was calculated by dividing the number of filled seed by total seed per panicle and then converted into percentage. 100-grain weight $(\mathrm{g})$, grain yield per stand (g/stand) was recorded after threshing.100-grains were counted, and weights were measured using electronic balance.

The data obtained were subjected to analysis of variance (ANOVA) using MINITAB, Version 17 statistical package. The means were separated using Tukey's Honestly Significant Difference (HSD) test at 5\% level of 
significance. Mean square values from the ANOVA tables for each character were used in estimating the phenotypic, genotypic and the environmental variances as well as the genotype by planting date interaction using the following equations:
Single planting date
$\mathrm{MSe}=\delta^{2} e$
Combined planting dates
$\delta^{2} g=\frac{\mathrm{MS} g-\mathrm{MSe}}{r}$
$\delta^{2} e=\mathrm{MSe}$
$\delta^{2} p=\delta^{2} g^{r}+\delta^{2} e$
$\delta^{2} g e=\frac{M S g e-\mathrm{MSe}}{r}$
$\delta^{2} g=\frac{\mathrm{MS} g-\stackrel{r}{\mathrm{MS} g e}}{r e}$
$\delta^{2} p=\delta^{2} g+\delta^{2} g e+\delta^{2} e$

Where: $\delta^{2} e=$ environmental variance, $\delta^{2} g=$ genotypic variance, $\delta^{2} g e=$ genotype x environment variance, $\delta^{2} p$ $=$ phenotypic variance, $\mathrm{MSe}=$ mean square of error, $\mathrm{MSg}=$ mean square of genotype, $\mathrm{MSge}=$ mean square of GxE, e $=$ number of environments, $\mathrm{r}=$ replications, Environments $=$ planting dates

Phenotypic and genotypic coefficients of variation were estimated according to the formulas of Singh and Chaudhary (1985) as follows:

$$
\begin{aligned}
& \text { Phenotypic coefficient of variation }(\mathrm{PCV})=\frac{\sqrt{\delta^{2} p}}{\bar{x}} \times 100 \\
& \text { Genotypic coefficient of variation }(\mathrm{GCV})=\frac{\sqrt{\delta^{2} g}}{\bar{x}} \times 100
\end{aligned}
$$

Where: $\bar{x}=$ Sample mean of the character being evaluated

The PCV and GCV values were categorized as high, medium and low as indicated by

Siva-Subramamian and Menon (1973) as follows:

High $=>20 \% ;$ Medium $=11-20 \%$; Low $=0-10 \%$

Heritability was estimated as the proportion of phenotypic variation that is due to genetic variation (Falconer and Mackay, 1996), and is defined as:

$$
\text { Heritability in broad sense }\left(\mathrm{H}^{2}{ }_{\mathrm{B}}\right)=\frac{\delta^{2} g}{\delta^{2} p} \times 100
$$

Heritability was categorized as high, medium and low according to the classification of Elrod and Stanfield (2002) as follows: High $=>50 \%$; Medium $=21-50 \%$; Low $=0-20 \%$

Genetic advance (GA) was computed according to the formula of Singh and Chaudhary (1985):

$$
G A=\frac{\delta^{2} g}{\sqrt{\delta^{2} p}} \times K
$$

Where, $\mathrm{K}=2.06$ (selection differential at $5 \%$ )

Genetic advance as percentage of the mean (GAM) also known as expected genetic gain (EGG) was computed according to the formula used by Prabhu et al., (2017).

$$
\mathrm{GAM}=\frac{\mathrm{GA} \times 100}{\overline{\mathrm{x}}}
$$

GAM was categorized as high, medium and low based on the classification of Johnson et al., (1955): High =>20\%; Moderate $=11-20 \% ;$ Low $=0-10 \%$ 
Table 1: Experimental materials used in the study

\begin{tabular}{lll}
\hline S/N & Variety & Source \\
\hline 1. & BG-90-2 & Ebonyi State University \\
2. & FARO 44 & Ebonyi State University \\
3. & FARO 61 & Ebonyi State University \\
4. & FARO 66 & Ebonyi State University \\
5. & FARO 67 & Ebonyi State University \\
6. & UPN 250 & University of port Harcourt \\
7. & UPN 266 & University of port Harcourt \\
8. & UPN 295 & University of port Harcourt \\
9. & UPN 318 & University of port Harcourt \\
10. & UPN 323 & University of port Harcourt \\
11. & UPN 313 & University of port Harcourt \\
12. & UPN 253 & University of port Harcourt \\
13. & UPN 288 & University of port Harcourt \\
14. & UPN 347 & University of port Harcourt \\
15. & UPN 324 & University of port Harcourt \\
16. & UPN 228 & University of port Harcourt \\
17. & UPN 336 & University of port Harcourt \\
18. & UPN 300 & University of port Harcourt \\
19. & UPN 268 & University of port Harcourt \\
20. & UPN 345 & University of port Harcourt \\
21. & UPN 349 & University of port Harcourt \\
22. & UPN 257 & University of port Harcourt \\
23. & Okporogwu & Ebonyi State University \\
24. & UPIA 1 & University of port Harcourt \\
25. & UPIA 2 & University of port Harcourt \\
\hline & &
\end{tabular}

\section{Results}

\section{Evaluation of variability and yield and yield components}

The mean squares obtained from the analysis of variance revealed that genotypic effect was significant $(\mathrm{P} \leq 0.01)$ and $(\mathrm{P} \leq 0.05)$ for all parameters evaluated in the two different planting dates except plant height and tiller number in planting date 1 . Combined analysis of variance across planting dates showed that there was significant $(\mathrm{P} \leq 0.01)$ variation among the rice varieties for all parameters evaluated. Significant planting date effect was observed for leaf area, days to $50 \%$ flowering, tiller number, panicle number, panicle length, spikelet fertility, number of grains per panicle and grain yield per stand. Variety by planting date interaction effect was significant $(\mathrm{P} \leq 0.01)$ for all parameters except plant height, tiller number, panicle number and 100-grain weight.

The individual planting dates and pooled mean performance of 25 rice varieties evaluated for phenological parameters is presented in Table 2. Varieties were significantly $(\mathrm{P} \leq 0.05)$ different for all parameters except tiller number in planting date 1. The mean plant height of the varieties in planting date 1 and planting date 2 was 76.26 and $73.95 \mathrm{~cm}$, which ranged from $61 \mathrm{~cm}$ (UPN 250) to $101.6 \mathrm{~cm}$ (UPIA 2) and 63.67 (UPN 268) to $106.07 \mathrm{~cm}$ (UPIA 2), respectively. Leaf area significantly varied from 8.38 to $38.39 \mathrm{~cm}^{2}$ in planting date 1 and 9.15 to 39.73 $\mathrm{cm}^{2}$ in planting date 2 both for UPN 345 and UPIA 2 with mean values of 22.45 and $18.01 \mathrm{~cm}^{2}$, respectively. The number of days to $50 \%$ flowering significantly varied among the 25 varieties studied, and ranged from 71 to 102.67 days in planting date 1 and 76.33 to 99.33 days in planting date 2, with mean value of 95.43 and 84.65 days, respectively. FARO 44 had the shortest flowering time of 71 and 76.33 days in the different planting dates while much delay in flowering was observed in UPN 347 (102.67 days) in planting date 1 and in FARO 66 (99.33) in planting date 2 .

The pooled mean values of the 25 rice varieties were also significant $(\mathrm{P} \leq 0.05)$ for all phenological parameters evaluated. Plant height ranged from 67.17 to $103.83 \mathrm{~cm}$ with a mean height of $75.09 \mathrm{~cm}$. Leaf area ranged from 8.76 to $39.06 \mathrm{~cm}^{2}$ with a mean value of $20.23 \mathrm{~cm}^{2}$. The number of days to $50 \%$ flowering had a mean value of 90.04 days, ranging from 73.67 to 100.17 days. On the other hand, tiller number ranged from 5.50 to 8.83.

The results of variability in yield parameters (panicle number, panicle weight, panicle length, spikelet fertility, number of grains per panicle, 100-grain weight and grain yield per stand) observed among the 25 rice varieties are shown in Table 3. In the two different planting dates, varieties were significantly $(\mathrm{P} \leq 0.05)$ different for all yield parameters evaluated except 100 -grain weight in planting date 2 . The mean panicle number per plant in planting date 1 was highest (8) in UPIA 2, while UPN 336 had the least panicle number per plant of 2.67. FARO 44 on the other hand had the highest (6) mean panicle number per plant in planting date 2 while UPN 336 and UPN 257 had the least (2.33) mean panicle number per plant. Mean panicle weight for planting date 1 was $1.65 \mathrm{~g}$ while for 
planting date 2 was $1.73 \mathrm{~g}$. UPIA $2(28.93 \mathrm{~cm})$ and UPN $253(26.33 \mathrm{~cm})$ had the longest panicles in planting dates 1 and 2, respectively while UPN $323(17.73 \mathrm{~cm})$ and UPN $345(3.31 \mathrm{~cm})$ were the varieties with the shortest panicles in planting dates 1 and 2, respectively. The mean spikelet fertility of the 25 rice varieties in planting dates 1 and 2 were 70.29 and 67.12, respectively and it ranged from 51.67 in BG-90-2 to 92.67 in FARO 44 and from 42.33 in UPN 318 to 92.33 in FARO 44, in planting dates 1 and 2, respectively. Number of grains per panicle was higher at planting date 1 than at planting date 2 with mean values of 95.69 and 80.85, respectively. UPN 228 with 174.33 grains per panicle and FARO 44 with 132 grains per panicle were the varieties with the highest number of grains per panicle in both planting dates 1 and 2, respectively. Conversely, FARO 61 and UPN 313 with 55 and 49.00 grains per panicle were the varieties with the least number of grains per panicle in both planting dates, respectively. Grain yield per stand in planting date 1 varied significantly $(\mathrm{P} \leq 0.05)$ and ranged from 1.49 to 7.27 $\mathrm{g} /$ plant with mean yield of $3.46 \mathrm{~g} /$ plant, while in planting date 2 , it ranged from 1.63 to $7.61 \mathrm{~g} / \mathrm{plant}$.

The pooled mean values of the varieties differed significantly $(\mathrm{P} \leq 0.05)$ for all yield parameters evaluated. Panicle number ranged from 2.5 (UPN 336) to 6.83 (UPIA 2) with grand mean of 4.45. UPN 318 had the least panicle weight of $1.06 \mathrm{~g}$, and differed significantly from UPIA 2 which had the highest panicle weight $(2.7 \mathrm{~g})$. Panicle length ranged from $15.54 \mathrm{~cm}$ in UPN 345 to $26.79 \mathrm{~cm}$ in UPIA 2 with a mean length of $20.43 \mathrm{~cm}$. The mean spikelet fertility among the 25 rice varieties was 68.7, and ranged from 52.33 (UPN 266) to 92.50 (FARO 44). Number of grains per panicle had a mean value of 88.27 , and ranged from 52.33 grains per panicle in UPN 313 to 133 grains per panicle in FARO 44. Okporogwu had the least $(1.75 \mathrm{~g})$ 100-grain weight differing significantly from FARO 44 which had the highest $(2.75 \mathrm{~g})$. The highest grain yield per stand was recorded in UPIA 2 with $7.44 \mathrm{~g} / \mathrm{stand}$, and was significantly $(\mathrm{P} \leq 0.05)$ different from all other varieties for this trait.

\section{Heritability and Genetic advance}

Pooled estimates of variance components, coefficients of variation, broad sense heritability, genetic advance and genetic advance as percent of the mean over two planting dates for 11 phenological and yield parameters in twentyfive rice varieties is presented in Table 4. The results showed the prominence of the environment and the genotype by environment interaction on the expression of some of the parameters. Only leaf area, panicle number, spikelet fertility and grain yield per stand have the contribution of genetic variance to phenotypic variance greater than 50 percent. Broad sense heritability estimate was found to be moderate (between $21-49 \%$ ) for majority of the parameters studied while tiller number had low $(<20 \%)$ heritability estimate.

Grain yield per stand had the highest phenotypic coefficient of variation (PCV) $(44.43 \%)$ and genotypic coefficient of variation (GCV) (33.21\%) values, whereas days to 50\% flowering had the least PCV (7.42\%) and GCV (4.48\%) values. Leaf area, panicle number, panicle weight and grain yield per stand recorded high GCV and PCV, whereas number of grains per panicle had moderate GCV and high PCV. At 5\% selection intensity, genetic advance ranged from 0.17 (100-grain weight) to 20.0 (number of grains per panicle). Although, comparisons cannot be made using these values since the units of measurement of these parameters are not the same. Genetic advance as the percentage of the mean (GAM), gives room for easy comparison among these parameters by equating the different units of measurements of genetic advance. It expresses the values of genetic advance as the percentage of the variety mean for each character. Results of GAM showed parameters such as leaf area, panicle number, panicle weight, number of grains per panicle and grain yield per stand with values greater than $20 \%$ had high genetic advance. Panicle length and spikelet fertility with values ranging between 11 and 19\% had moderate genetic advance, while plant height, days to $50 \%$ flowering, tiller number, and 100 -grain weight with GAM values less than $10 \%$ have low genetic advance. 
Table 2: Mean values of phenological parameters of the 25 rice varieties

\begin{tabular}{|c|c|c|c|c|c|c|c|c|c|c|c|c|}
\hline \multirow[b]{2}{*}{ Variety } & \multicolumn{4}{|c|}{ Planting date 1} & \multicolumn{4}{|c|}{ Planting date 2} & \multicolumn{4}{|c|}{ Combined } \\
\hline & $\begin{array}{l}\begin{array}{l}\mathrm{PH} \\
(\mathrm{cm})\end{array} \\
\end{array}$ & $\begin{array}{l}\mathrm{LA} \\
\left(\mathrm{cm}^{2}\right)\end{array}$ & DTF & $\mathrm{TN}$ &  & $\begin{array}{l}\mathrm{LA} \\
\left(\mathrm{cm}^{2}\right)\end{array}$ & DTF & $\mathrm{TN}$ & $\begin{array}{l}\mathrm{PH} \\
(\mathrm{cm})\end{array}$ & $\begin{array}{l}\text { LA } \\
\left(\mathrm{cm}^{2}\right)\end{array}$ & DTF & $\mathrm{TN}$ \\
\hline BG-90-2 & $70.00 \mathrm{ab}$ & $23.00 \mathrm{c}-\mathrm{e}$ & $97.00 \mathrm{a}-\mathrm{c}$ & $7.33 \mathrm{a}$ & $65.33 b$ & $18.76 \mathrm{c}-\mathrm{e}$ & $92.67 \mathrm{ab}$ & $7.00 \mathrm{ab}$ & $67.67 \mathrm{~b}$ & $20.88 \mathrm{~cd}$ & $94.83 \mathrm{a}-\mathrm{e}$ & $7.17 \mathrm{ab}$ \\
\hline FARO 44 & $81.33 \mathrm{ab}$ & $30.25 \mathrm{c}$ & $71.00 \mathrm{e}$ & $7.00 \mathrm{a}$ & $79.00 \mathrm{~b}$ & $30.84 \mathrm{ab}$ & $76.33 \mathrm{~g}$ & $7.00 \mathrm{ab}$ & $80.17 \mathrm{~b}$ & $30.54 b$ & $73.67 \mathrm{i}$ & $7.00 \mathrm{ab}$ \\
\hline FARO 61 & 69.33ab & $23.02 \mathrm{c}-\mathrm{e}$ & $94.00 \mathrm{~b}-\mathrm{d}$ & $9.00 \mathrm{a}$ & $67.67 \mathrm{~b}$ & $14.35 \mathrm{c}-\mathrm{e}$ & $82.67 \mathrm{c}-\mathrm{g}$ & $6.33 \mathrm{ab}$ & $68.50 \mathrm{~b}$ & $18.69 \mathrm{c}-\mathrm{f}$ & $88.33 \mathrm{f}-\mathrm{h}$ & 7.67ab \\
\hline FARO 66 & $69.67 \mathrm{ab}$ & $23.32 \mathrm{c}-\mathrm{e}$ & $101.00 \mathrm{ab}$ & $9.33 \mathrm{a}$ & $80.33 b$ & $15.44 \mathrm{c}-\mathrm{e}$ & $99.33 \mathrm{a}$ & $8.33 \mathrm{a}$ & $75.00 \mathrm{~b}$ & $19.38 \mathrm{c}-\mathrm{e}$ & $100.17 \mathrm{a}$ & $8.83 \mathrm{a}$ \\
\hline FARO 67 & $71.00 \mathrm{ab}$ & $23.11 \mathrm{c}-\mathrm{e}$ & $94.67 b-d$ & $9.00 \mathrm{a}$ & $78.67 \mathrm{~b}$ & $19.11 \mathrm{c}-\mathrm{e}$ & $90.67 \mathrm{bc}$ & $6.00 \mathrm{ab}$ & $74.83 \mathrm{~b}$ & $21.11 \mathrm{~cd}$ & $92.67 b-f$ & $7.50 \mathrm{ab}$ \\
\hline UPN 250 & $61.00 \mathrm{~b}$ & $26.19 b c$ & $101.00 \mathrm{ab}$ & $7.00 \mathrm{a}$ & $73.33 b$ & $12.12 \mathrm{de}$ & $88.00 \mathrm{~b}-\mathrm{e}$ & $6.33 \mathrm{ab}$ & $67.17 \mathrm{~b}$ & $19.15 \mathrm{c}-\mathrm{e}$ & $94.50 \mathrm{~b}-\mathrm{e}$ & $6.67 \mathrm{ab}$ \\
\hline UPN 266 & 76.67ab & $21.12 \mathrm{c}-\mathrm{f}$ & $98.00 \mathrm{a}-\mathrm{c}$ & $8.33 \mathrm{a}$ & $68.33 b$ & $15.51 \mathrm{c}-\mathrm{e}$ & $82.67 \mathrm{c}-\mathrm{g}$ & $6.67 \mathrm{ab}$ & $72.50 \mathrm{~b}$ & $18.31 \mathrm{c}-\mathrm{f}$ & $90.33 \mathrm{~d}-\mathrm{h}$ & $7.50 \mathrm{ab}$ \\
\hline UPN 295 & 76.67ab & $18.69 \mathrm{~d}-\mathrm{g}$ & $94.33 b-d$ & $7.33 \mathrm{a}$ & $72.00 \mathrm{~b}$ & $17.06 \mathrm{c}-\mathrm{e}$ & $90.00 \mathrm{~b}-\mathrm{d}$ & $4.67 \mathrm{~b}$ & $74.33 \mathrm{~b}$ & $17.87 \mathrm{c}-\mathrm{f}$ & $92.17 \mathrm{~b}-\mathrm{g}$ & $6.00 \mathrm{ab}$ \\
\hline UPN 318 & $67.33 \mathrm{ab}$ & $22.76 \mathrm{c}-\mathrm{e}$ & $95.67 \mathrm{a}-\mathrm{c}$ & $8.00 \mathrm{a}$ & $80.00 \mathrm{~b}$ & $16.62 \mathrm{c}-\mathrm{e}$ & $78.67 \mathrm{fg}$ & $4.67 \mathrm{~b}$ & $73.67 \mathrm{~b}$ & $19.69 \mathrm{c}-\mathrm{e}$ & $87.17 \mathrm{f}-\mathrm{h}$ & $6.33 \mathrm{ab}$ \\
\hline UPN 323 & 75.33ab & $18.18 \mathrm{e}-\mathrm{g}$ & $96.67 \mathrm{a}-\mathrm{c}$ & $7.33 \mathrm{a}$ & $74.33 b$ & $14.17 \mathrm{c}-\mathrm{e}$ & $77.33 \mathrm{~g}$ & $6.00 \mathrm{ab}$ & $74.83 \mathrm{~b}$ & $16.18 \mathrm{~d}-\mathrm{f}$ & $87.00 \mathrm{gh}$ & $6.67 \mathrm{ab}$ \\
\hline UPN 313 & 78.00ab & $22.48 \mathrm{c}-\mathrm{e}$ & $94.67 b-d$ & $6.67 \mathrm{a}$ & $80.00 \mathrm{~b}$ & $13.50 \mathrm{c}-\mathrm{e}$ & $81.33 \mathrm{e}-\mathrm{g}$ & $6.67 \mathrm{ab}$ & $79.00 \mathrm{~b}$ & $17.99 \mathrm{c}-\mathrm{f}$ & $88.00 \mathrm{f}-\mathrm{h}$ & $6.67 a b$ \\
\hline UPN 253 & 74.00ab & $21.37 \mathrm{c}-\mathrm{e}$ & $93.67 b-d$ & $5.67 \mathrm{a}$ & $75.00 \mathrm{~b}$ & $16.83 \mathrm{c}-\mathrm{e}$ & $77.67 \mathrm{~g}$ & $5.33 \mathrm{ab}$ & $74.50 \mathrm{~b}$ & $19.10 \mathrm{c}-\mathrm{f}$ & $85.67 \mathrm{~h}$ & $5.50 \mathrm{~b}$ \\
\hline UPN 288 & 79.33ab & $22.34 \mathrm{c}-\mathrm{e}$ & $98.33 \mathrm{a}-\mathrm{c}$ & $6.33 \mathrm{a}$ & $73.00 \mathrm{~b}$ & $17.93 \mathrm{c}-\mathrm{e}$ & $87.00 b-f$ & $5.67 \mathrm{ab}$ & $76.17 \mathrm{~b}$ & $20.14 \mathrm{c}-\mathrm{e}$ & $92.67 b-f$ & $6.00 \mathrm{ab}$ \\
\hline UPN 347 & 70.33ab & $26.78 b c$ & $102.67 \mathrm{a}$ & $6.67 \mathrm{a}$ & $69.67 \mathrm{~b}$ & $17.60 \mathrm{c}-\mathrm{e}$ & $87.33 \mathrm{~b}-\mathrm{e}$ & $6.00 \mathrm{ab}$ & $70.00 \mathrm{~b}$ & $22.19 \mathrm{c}$ & $95.00 \mathrm{a}-\mathrm{d}$ & $6.33 \mathrm{ab}$ \\
\hline UPN 324 & 79.67ab & $21.14 c-f$ & $97.33 \mathrm{a}-\mathrm{c}$ & $8.00 \mathrm{a}$ & $73.00 \mathrm{~b}$ & $20.79 b-d$ & $87.33 \mathrm{~b}-\mathrm{e}$ & $6.33 \mathrm{ab}$ & $76.33 b$ & $20.97 \mathrm{~cd}$ & $92.33 \mathrm{~b}-\mathrm{g}$ & 7.17ab \\
\hline UPN 228 & 72.00ab & $24.46 \mathrm{bc}$ & $97.33 \mathrm{a}-\mathrm{c}$ & $7.33 \mathrm{a}$ & $76.67 \mathrm{~b}$ & $21.26 \mathrm{~b}-\mathrm{d}$ & $81.33 \mathrm{e}-\mathrm{g}$ & $4.67 \mathrm{~b}$ & $74.33 b$ & $22.86 \mathrm{c}$ & $89.33 \mathrm{e}-\mathrm{h}$ & $6.00 \mathrm{ab}$ \\
\hline UPN 336 & 83.67ab & $21.22 \mathrm{c}-\mathrm{f}$ & $92.00 \mathrm{~cd}$ & $9.33 \mathrm{a}$ & $66.33 b$ & $23.11 b c$ & $78.00 \mathrm{~g}$ & $6.67 \mathrm{ab}$ & $75.00 \mathrm{~b}$ & $22.17 \mathrm{c}$ & $85.00 \mathrm{~h}$ & $8.00 \mathrm{ab}$ \\
\hline UPN 300 & $33 a b$ & $23.94 \mathrm{c}-\mathrm{e}$ & $97.67 \mathrm{a}-\mathrm{c}$ & $8.67 \mathrm{a}$ & $66.67 \mathrm{~b}$ & $15.26 \mathrm{c}-\mathrm{e}$ & $76.33 \mathrm{~g}$ & $6.00 \mathrm{ab}$ & $75.50 \mathrm{~b}$ & $19.60 \mathrm{c}-\mathrm{e}$ & $87.00 \mathrm{gh}$ & 7.33ab \\
\hline UPN 268 & $73.00 \mathrm{ab}$ & $15.31 \mathrm{fg}$ & $94.67 b-d$ & $6.33 \mathrm{a}$ & $63.67 \mathrm{~b}$ & $14.00 \mathrm{c}-\mathrm{e}$ & $76.67 \mathrm{~g}$ & $5.67 \mathrm{ab}$ & $68.33 b$ & $14.66 \mathrm{ef}$ & $85.67 \mathrm{~h}$ & $6.00 \mathrm{ab}$ \\
\hline UPN 345 & $82.00 \mathrm{ab}$ & $8.38 \mathrm{~h}$ & $96.33 \mathrm{a}-\mathrm{c}$ & $8.67 \mathrm{a}$ & $72.67 \mathrm{~b}$ & $9.15 \mathrm{e}$ & $78.00 \mathrm{~g}$ & $5.67 \mathrm{ab}$ & $77.33 b$ & $8.76 \mathrm{~g}$ & $87.17 \mathrm{f}-\mathrm{h}$ & 7.17ab \\
\hline UPN 349 & 83.67ab & $22.42 \mathrm{c}-\mathrm{e}$ & $97.00 \mathrm{a}-\mathrm{c}$ & $7.00 \mathrm{a}$ & $72.33 b$ & $17.98 \mathrm{c}-\mathrm{e}$ & $82.00 \mathrm{~d}-\mathrm{g}$ & $5.33 \mathrm{ab}$ & $78.00 \mathrm{~b}$ & $20.20 \mathrm{c}-\mathrm{e}$ & $89.50 \mathrm{~d}-\mathrm{h}$ & $6.17 \mathrm{ab}$ \\
\hline UPN 257 & 79.67ab & $25.13 b c$ & $100.67 \mathrm{ab}$ & $6.67 \mathrm{a}$ & $67.33 b$ & $21.31 \mathrm{~b}-\mathrm{d}$ & $94.67 \mathrm{ab}$ & $6.67 a b$ & $73.50 \mathrm{~b}$ & $23.22 \mathrm{c}$ & $97.67 \mathrm{ab}$ & $6.67 \mathrm{ab}$ \\
\hline Okporogwu & 74.67ab & $14.29 \mathrm{gh}$ & $98.00 \mathrm{a}-\mathrm{c}$ & $8.67 \mathrm{a}$ & $78.33 b$ & $12.62 \mathrm{de}$ & $95.00 \mathrm{ab}$ & $7.67 \mathrm{ab}$ & $76.50 \mathrm{~b}$ & $13.45 \mathrm{fg}$ & $96.50 \mathrm{a}-\mathrm{c}$ & $8.17 \mathrm{ab}$ \\
\hline UPIA 1 & 72.33ab & $23.97 \mathrm{c}-\mathrm{e}$ & $94.67 b-d$ & $9.67 \mathrm{a}$ & $68.00 \mathrm{~b}$ & $15.13 \mathrm{c}-\mathrm{e}$ & $88.33 b-e$ & $6.67 \mathrm{ab}$ & $70.17 \mathrm{~b}$ & $19.55 \mathrm{c}-\mathrm{e}$ & $91.50 \mathrm{c}-\mathrm{g}$ & $8.17 \mathrm{ab}$ \\
\hline UPIA 2 & $101.60 \mathrm{a}$ & $38.39 \mathrm{a}$ & $87.33 d$ & $8.00 \mathrm{a}$ & $106.07 \mathrm{a}$ & $39.73 \mathrm{a}$ & $87.00 \mathrm{~b}-\mathrm{f}$ & $5.33 \mathrm{ab}$ & $103.83 \mathrm{a}$ & $39.06 \mathrm{a}$ & $87.17 \mathrm{f}-\mathrm{h}$ & $6.67 \mathrm{ab}$ \\
\hline S. E & 1.43 & 0.65 & 0.72 & 0.20 & 1.15 & 0.77 & 0.80 & 0.15 & 0.92 & 0.53 & 0.70 & 0.14 \\
\hline Grand Mean & 76.26 & 22.45 & 95.43 & 7.73 & 73.91 & 18.01 & 84.65 & 6.13 & 75.09 & 20.23 & 90.04 & 6.93 \\
\hline
\end{tabular}

Means that do not share a letter are significantly different at $\mathrm{p} \leq 0.05$ probability level.

$\mathrm{PH}=$ Plant height, $\mathrm{LA}=$ Leaf area, $\mathrm{DTF}=$ Days to $50 \%$ flowering, $\mathrm{TN}=$ Tiller number, $\mathrm{S} . \mathrm{E}=\mathrm{Standard}$ error

Table 3: Mean values of yield parameters of the 25 rice varieties

\begin{tabular}{|c|c|c|c|c|c|c|c|c|c|c|c|c|c|c|}
\hline \multirow[b]{2}{*}{ Variety } & \multicolumn{7}{|c|}{ Planting date 1} & \multicolumn{7}{|c|}{ Planting date 2} \\
\hline & PN & $\mathrm{PW}$ & PL & $\mathrm{SF}$ & NOGPP & $100 \mathrm{GW}$ & GYLD & PN & $\mathrm{PW}$ & PL & SF & NOGPP & $100 \mathrm{GW}$ & GYLD \\
\hline BG-90-2 & $4.67 \mathrm{~b}-\mathrm{e}$ & $1.71 \mathrm{~b}-\mathrm{e}$ & $20.10 b-f$ & $51.67 \mathrm{~g}$ & $69.33 \mathrm{~g}-\mathrm{i}$ & $2.30 \mathrm{ab}$ & $2.72 \mathrm{fg}$ & $3.67 \mathrm{~b}-\mathrm{e}$ & $1.84 \mathrm{a}-\mathrm{f}$ & $19.40 \mathrm{a}-\mathrm{d}$ & 63.67b-h & $77.33 \mathrm{c}-\mathrm{h}$ & $2.60 \mathrm{a}$ & $4.52 \mathrm{c}-\mathrm{e}$ \\
\hline FARO 44 & $6.67 \mathrm{ab}$ & $2.48 \mathrm{ab}$ & $24.35 \mathrm{a}-\mathrm{c}$ & $92.67 \mathrm{a}$ & 134.00a-d & $2.65 \mathrm{a}$ & $5.95 \mathrm{ab}$ & $6.00 \mathrm{a}$ & $2.69 \mathrm{a}$ & $24.77 \mathrm{ab}$ & $92.33 \mathrm{a}$ & $132.00 \mathrm{a}$ & $2.86 \mathrm{a}$ & $4.37 \mathrm{c}-\mathrm{e}$ \\
\hline FARO 61 & $4.33 \mathrm{~b}-\mathrm{e}$ & $1.84 \mathrm{a}-\mathrm{e}$ & $21.13 b-f$ & $66.67 \mathrm{~d}-\mathrm{g}$ & $55.00 \mathrm{i}$ & $2.32 \mathrm{ab}$ & $5.14 \mathrm{bc}$ & $3.67 \mathrm{~b}-\mathrm{e}$ & $1.46 \mathrm{c}-\mathrm{f}$ & $20.90 \mathrm{a}-\mathrm{d}$ & 63.33b-h & $65.00 \mathrm{f}-\mathrm{h}$ & $2.12 \mathrm{a}$ & $4.05 \mathrm{c}-\mathrm{g}$ \\
\hline FARO 66 & $6.67 \mathrm{ab}$ & $2.11 \mathrm{a}-\mathrm{d}$ & $25.17 \mathrm{ab}$ & $80.78 \mathrm{a}-\mathrm{e}$ & 151.00ab & $2.05 \mathrm{ab}$ & $5.12 \mathrm{bc}$ & $5.33 \mathrm{a}-\mathrm{c}$ & $2.22 \mathrm{a}-\mathrm{e}$ & $20.13 \mathrm{a}-\mathrm{d}$ & $79.10 \mathrm{a}-\mathrm{c}$ & 73.33d-h & $2.23 \mathrm{a}$ & $4.72 \mathrm{~cd}$ \\
\hline FARO 67 & $6.33 \mathrm{a}-\mathrm{c}$ & $1.79 \mathrm{a}-\mathrm{e}$ & $24.38 \mathrm{a}-\mathrm{c}$ & $70.00 \mathrm{~b}-\mathrm{g}$ & $119.67 \mathrm{~b}-\mathrm{e}$ & $2.21 \mathrm{ab}$ & $1.49 \mathrm{~g}$ & $4.67 \mathrm{a}-\mathrm{d}$ & $1.76 \mathrm{a}-\mathrm{f}$ & 19.10a-d & $53.67 \mathrm{e}-\mathrm{h}$ & $111.33 \mathrm{a}-\mathrm{c}$ & $1.90 \mathrm{a}$ & $1.91 \mathrm{j}-1$ \\
\hline UPN 250 & $4.67 \mathrm{~b}-\mathrm{e}$ & $1.75 \mathrm{a}-\mathrm{e}$ & $21.20 \mathrm{~b}-\mathrm{f}$ & $56.37 \mathrm{fg}$ & $120.00 \mathrm{~b}-\mathrm{e}$ & $1.75 \mathrm{~b}$ & $2.58 \mathrm{fg}$ & $4.33 \mathrm{a}-\mathrm{e}$ & $1.34 \mathrm{c}-\mathrm{f}$ & $18.37 b-d$ & $54.33 \mathrm{e}-\mathrm{h}$ & $61.33 \mathrm{f}-\mathrm{h}$ & $2.31 \mathrm{a}$ & $2.58 \mathrm{~h}-1$ \\
\hline UPN 266 & $4.33 \mathrm{~b}-\mathrm{e}$ & $1.87 \mathrm{a}-\mathrm{e}$ & $19.40 \mathrm{~d}-\mathrm{f}$ & $59.33 \mathrm{fg}$ & $109.67 \mathrm{~b}-\mathrm{g}$ & 2.24ab & $2.51 \mathrm{fg}$ & $2.67 \mathrm{de}$ & $1.82 \mathrm{a}-\mathrm{f}$ & $20.03 a-d$ & $45.33 \mathrm{gh}$ & $105.00 \mathrm{a}-\mathrm{e}$ & $2.33 \mathrm{a}$ & 1.631 \\
\hline UPN 295 & $4.33 \mathrm{~b}-\mathrm{e}$ & $1.10 \mathrm{de}$ & $19.30 \mathrm{~d}-\mathrm{f}$ & $73.01 \mathrm{~b}-\mathrm{f}$ & $64.67 \mathrm{hi}$ & $1.99 \mathrm{ab}$ & $2.65 \mathrm{fg}$ & $3.33 \mathrm{c}-\mathrm{e}$ & $1.50 \mathrm{c}-\mathrm{f}$ & $15.43 \mathrm{~cd}$ & $79.00 \mathrm{a}-\mathrm{c}$ & $55.67 \mathrm{gh}$ & $2.13 \mathrm{a}$ & $1.97 \mathrm{j}-\mathrm{i}$ \\
\hline UPN 318 & 5.33a-e & $1.07 \mathrm{de}$ & $20.07 \mathrm{~b}-\mathrm{f}$ & 75.32a-f & $67.33 \mathrm{~g}-\mathrm{i}$ & $1.97 \mathrm{ab}$ & $4.92 \mathrm{~b}-\mathrm{d}$ & $4.33 \mathrm{a}-\mathrm{e}$ & $1.05 \mathrm{f}$ & $18.23 \mathrm{~b}-\mathrm{d}$ & $42.33 \mathrm{~h}$ & 64.67f-h & $2.21 \mathrm{a}$ & $4.28 \mathrm{c}-\mathrm{e}$ \\
\hline UPN 323 & 5.33a-e & $1.55 \mathrm{~b}-\mathrm{e}$ & $17.73 \mathrm{f}$ & $79.17 \mathrm{a}-\mathrm{e}$ & $73.67 \mathrm{~g}-\mathrm{i}$ & $2.63 \mathrm{a}$ & $4.79 \mathrm{~b}-\mathrm{e}$ & $4.33 \mathrm{a}-\mathrm{e}$ & $1.57 \mathrm{~b}-\mathrm{f}$ & $17.90 \mathrm{~b}-\mathrm{d}$ & $82.00 \mathrm{a}-\mathrm{c}$ & $53.67 \mathrm{gh}$ & $2.64 \mathrm{a}$ & $3.44 \mathrm{~d}-\mathrm{i}$ \\
\hline UPN 313 & $4.33 \mathrm{~b}-\mathrm{e}$ & $1.05 \mathrm{de}$ & $22.87 \mathrm{~b}-\mathrm{e}$ & $58.70 \mathrm{fg}$ & $55.67 \mathrm{i}$ & $2.14 \mathrm{ab}$ & $2.64 \mathrm{fg}$ & $3.00 \mathrm{de}$ & $1.37 \mathrm{c}-\mathrm{f}$ & $18.00 \mathrm{~b}-\mathrm{d}$ & $60.33 \mathrm{c}-\mathrm{h}$ & $49.00 \mathrm{~h}$ & $2.31 \mathrm{a}$ & $3.33 \mathrm{~d}-\mathrm{j}$ \\
\hline UPN 253 & $4.67 \mathrm{~b}-\mathrm{e}$ & $1.77 \mathrm{a}-\mathrm{e}$ & $25.17 \mathrm{ab}$ & 79.33a-e & $103.00 \mathrm{c}-\mathrm{h}$ & $2.53 \mathrm{ab}$ & $4.80 \mathrm{~b}-\mathrm{e}$ & $3.67 \mathrm{~b}-\mathrm{e}$ & $2.12 \mathrm{a}-\mathrm{f}$ & $26.33 \mathrm{a}$ & $85.00 \mathrm{ab}$ & $94.33 b-f$ & $1.89 \mathrm{a}$ & $4.04 \mathrm{c}-\mathrm{g}$ \\
\hline UPN 288 & $4.67 \mathrm{~b}-\mathrm{e}$ & $1.34 \mathrm{c}-\mathrm{e}$ & $21.93 b-f$ & $64.01 \mathrm{e}-\mathrm{g}$ & $75.33 \mathrm{f}-\mathrm{i}$ & 2.14ab & $1.75 \mathrm{~g}$ & $3.67 \mathrm{~b}-\mathrm{e}$ & $1.32 \mathrm{~d}-\mathrm{f}$ & $21.80 \mathrm{a}-\mathrm{c}$ & $56.33 \mathrm{~d}-\mathrm{h}$ & $86.33 \mathrm{c}-\mathrm{g}$ & $1.90 \mathrm{a}$ & $1.83 \mathrm{kl}$ \\
\hline UPN 347 & $4.67 \mathrm{~b}-\mathrm{e}$ & $1.54 \mathrm{~b}-\mathrm{e}$ & $22.00 \mathrm{~b}-\mathrm{f}$ & $75.35 \mathrm{a}-\mathrm{f}$ & $85.33 \mathrm{e}-\mathrm{i}$ & $1.91 \mathrm{ab}$ & $2.32 \mathrm{fg}$ & $3.00 \mathrm{de}$ & $1.48 \mathrm{c}-\mathrm{f}$ & $18.80 \mathrm{a}-\mathrm{d}$ & $60.00 \mathrm{c}-\mathrm{h}$ & 70.67e-h & $1.78 \mathrm{a}$ & 2.46i-1 \\
\hline UPN 324 & $5.67 \mathrm{a}-\mathrm{d}$ & $1.29 \mathrm{c}-\mathrm{e}$ & $21.13 b-f$ & $62.33 \mathrm{e}-\mathrm{g}$ & $88.33 \mathrm{e}-\mathrm{i}$ & $2.46 \mathrm{ab}$ & $5.11 \mathrm{bc}$ & $3.67 \mathrm{~b}-\mathrm{e}$ & $1.90 \mathrm{a}-\mathrm{f}$ & $19.57 \mathrm{a}-\mathrm{d}$ & $59.67 \mathrm{c}-\mathrm{h}$ & $88.00 \mathrm{c}-\mathrm{g}$ & $2.17 \mathrm{a}$ & $4.02 \mathrm{c}-\mathrm{h}$ \\
\hline UPN 228 & $5.67 \mathrm{a}-\mathrm{d}$ & $1.65 \mathrm{~b}-\mathrm{e}$ & $22.70 \mathrm{~b}-\mathrm{e}$ & $86.43 \mathrm{a}-\mathrm{c}$ & $174.33 \mathrm{a}$ & $2.03 \mathrm{ab}$ & $4.95 \mathrm{~b}-\mathrm{d}$ & $5.67 \mathrm{ab}$ & $1.69 \mathrm{a}-\mathrm{f}$ & $16.57 \mathrm{~cd}$ & $80.33 a-c$ & $67.33 \mathrm{f}-\mathrm{h}$ & $2.05 \mathrm{a}$ & $4.95 \mathrm{c}$ \\
\hline UPN 336 & $2.67 \mathrm{e}$ & $2.09 \mathrm{a}-\mathrm{d}$ & $21.43 b-f$ & $57.00 \mathrm{fg}$ & $118.33 \mathrm{~b}-\mathrm{f}$ & $2.41 \mathrm{ab}$ & $1.50 \mathrm{~g}$ & $2.33 \mathrm{e}$ & $2.44 a-c$ & $15.11 \mathrm{~cd}$ & $79.67 \mathrm{a}-\mathrm{c}$ & $125.33 \mathrm{ab}$ & $1.96 \mathrm{a}$ & $3.56 \mathrm{c}-\mathrm{i}$ \\
\hline UPN 300 & 5.33a-e & $1.47 \mathrm{~b}-\mathrm{e}$ & $21.20 b-f$ & $58.50 \mathrm{fg}$ & $94.33 \mathrm{~d}-\mathrm{i}$ & $2.11 \mathrm{ab}$ & $1.68 \mathrm{~g}$ & $4.33 \mathrm{a}-\mathrm{e}$ & $1.51 \mathrm{~b}-\mathrm{f}$ & $18.03 b-d$ & $62.00 \mathrm{c}-\mathrm{h}$ & $95.33 \mathrm{~b}-\mathrm{f}$ & $1.90 \mathrm{a}$ & $2.77 \mathrm{f}-1$ \\
\hline UPN 268 & $5.33 \mathrm{a}-\mathrm{e}$ & $1.82 \mathrm{a}-\mathrm{e}$ & $19.40 \mathrm{~d}-\mathrm{f}$ & $68.00 \mathrm{~b}-\mathrm{g}$ & $84.33 \mathrm{e}-\mathrm{i}$ & $1.96 \mathrm{ab}$ & $2.80 \mathrm{e}-\mathrm{g}$ & $3.67 \mathrm{~b}-\mathrm{e}$ & $1.83 \mathrm{a}-\mathrm{f}$ & $20.60 \mathrm{a}-\mathrm{d}$ & $68.33 \mathrm{~b}-\mathrm{f}$ & $107.33 \mathrm{a}-\mathrm{d}$ & $2.10 \mathrm{a}$ & $2.69 \mathrm{~g}-1$ \\
\hline UPN 345 & $3.00 \mathrm{de}$ & $1.05 \mathrm{de}$ & $17.77 \mathrm{f}$ & $84.67 \mathrm{a}-\mathrm{d}$ & $69.33 \mathrm{~g}-\mathrm{i}$ & $2.26 \mathrm{ab}$ & $2.72 \mathrm{fg}$ & $2.67 \mathrm{de}$ & $1.42 \mathrm{c}-\mathrm{f}$ & $13.31 \mathrm{~d}$ & 74.33a-e & $56.00 \mathrm{gh}$ & $1.79 \mathrm{a}$ & $3.12 \mathrm{e}-\mathrm{k}$ \\
\hline UPN 349 & $4.33 \mathrm{~b}-\mathrm{e}$ & $2.35 \mathrm{a}-\mathrm{c}$ & $23.23 \mathrm{~b}-\mathrm{e}$ & $67.67 \mathrm{c}-\mathrm{g}$ & $87.33 \mathrm{e}-\mathrm{i}$ & $2.33 \mathrm{ab}$ & $2.35 \mathrm{fg}$ & $2.67 \mathrm{de}$ & $1.12 \mathrm{ef}$ & $17.67 \mathrm{~b}-\mathrm{d}$ & $65.00 \mathrm{~b}-\mathrm{g}$ & $83.00 \mathrm{c}-\mathrm{h}$ & $1.98 \mathrm{a}$ & $4.18 \mathrm{c}-\mathrm{f}$ \\
\hline UPN 257 & $3.67 \mathrm{c}-\mathrm{e}$ & $0.99 \mathrm{e}$ & $21.53 \mathrm{~b}-\mathrm{f}$ & $72.95 \mathrm{~b}-\mathrm{f}$ & $100.67 \mathrm{c}-\mathrm{h}$ & $2.06 \mathrm{ab}$ & $2.98 \mathrm{~d}-\mathrm{g}$ & $2.33 \mathrm{e}$ & $1.68 \mathrm{a}-\mathrm{f}$ & 19.11a-d & 73.00a-e & $94.67 \mathrm{~b}-\mathrm{f}$ & $1.74 \mathrm{a}$ & 2.49i-1 \\
\hline Okporogwu & 5.33a-e & $1.26 \mathrm{de}$ & $18.73 \mathrm{ef}$ & $62.00 \mathrm{e}-\mathrm{g}$ & $67.33 \mathrm{~g}-\mathrm{i}$ & $1.68 \mathrm{~b}$ & $3.85 \mathrm{c}-\mathrm{f}$ & $4.00 \mathrm{a}-\mathrm{e}$ & $1.28 \mathrm{~d}-\mathrm{f}$ & $15.23 \mathrm{~cd}$ & $50.39 \mathrm{f}-\mathrm{h}$ & $60.67 \mathrm{f}-\mathrm{h}$ & $1.82 \mathrm{a}$ & $4.99 \mathrm{bc}$ \\
\hline UPIA 1 & $6.00 \mathrm{a}-\mathrm{c}$ & $1.39 \mathrm{c}-\mathrm{e}$ & $23.90 b-d$ & $68.00 \mathrm{~b}-\mathrm{g}$ & $82.67 \mathrm{e}-\mathrm{i}$ & $2.35 \mathrm{ab}$ & $1.89 \mathrm{fg}$ & $4.00 \mathrm{a}-\mathrm{e}$ & $2.27 \mathrm{a}-\mathrm{d}$ & $17.67 \mathrm{~b}-\mathrm{d}$ & $69.90 \mathrm{~b}-\mathrm{f}$ & 69.33f-h & $2.69 \mathrm{a}$ & $6.44 \mathrm{ab}$ \\
\hline UPIA 2 & $8.00 \mathrm{a}$ & $2.79 \mathrm{a}$ & $28.93 \mathrm{a}$ & $87.36 \mathrm{ab}$ & $141.67 \mathrm{a}-\mathrm{c}$ & $2.01 \mathrm{ab}$ & $7.27 \mathrm{a}$ & $5.67 \mathrm{ab}$ & $2.61 \mathrm{ab}$ & $24.66 \mathrm{ab}$ & $78.51 \mathrm{a}-\mathrm{d}$ & $74.67 \mathrm{~d}-\mathrm{h}$ & $2.31 \mathrm{a}$ & $7.61 \mathrm{a}$ \\
\hline S. E & 0.16 & 0.06 & 0.33 & 1.39 & 3.79 & 0.04 & 0.19 & 0.13 & 0.06 & 0.42 & 1.63 & 2.80 & 0.05 & 0.17 \\
\hline Grand Mean & 5.04 & 1.65 & 21.79 & 70.29 & 95.69 & 2.18 & 3.46 & 3.87 & 1.73 & 19.07 & 67.12 & 80.85 & 2.15 & 3.68 \\
\hline
\end{tabular}

Means that do not share a letter are significantly different at $\mathrm{p} \leq 0.05$ probability level.

$\mathrm{PN}=$ Panicle number, $\mathrm{PW}=$ Panicle weight, $\mathrm{PL}=$ Panicle length, $\mathrm{SF}=$ Spikelet fertility, NOGPP $=$ Number of grains per panicle, $100 \mathrm{GW}=100$-grain weight, $\mathrm{GYLD}=$ Grain yield per stand, $\mathrm{S} . \mathrm{E}=$ Standard error 
Table 3 (contd.): Mean values of yield parameters of the 25 rice varieties

\begin{tabular}{|c|c|c|c|c|c|c|c|}
\hline \multirow[t]{2}{*}{ Variety } & \multicolumn{7}{|c|}{ Combined } \\
\hline & $\mathrm{PN}$ & PW & $\mathrm{PL}$ & SF & NOGPP & $100 \mathrm{GW}$ & GYLD \\
\hline BG-90-2 & $4.17 \mathrm{~d}-\mathrm{i}$ & $1.77 \mathrm{c}-\mathrm{f}$ & $19.75 \mathrm{~d}-\mathrm{g}$ & $57.67 \mathrm{ij}$ & $73.33 \mathrm{f}-\mathrm{j}$ & $2.45 \mathrm{a}-\mathrm{c}$ & $3.62 \mathrm{c}-\mathrm{g}$ \\
\hline FARO 44 & $6.33 \mathrm{ab}$ & $2.59 \mathrm{ab}$ & $24.56 \mathrm{a}-\mathrm{c}$ & $92.50 \mathrm{a}$ & $133.00 \mathrm{a}$ & $2.75 \mathrm{a}$ & $5.16 \mathrm{~b}$ \\
\hline FARO 61 & $4.00 \mathrm{~d}-\mathrm{i}$ & $1.65 \mathrm{c}-\mathrm{f}$ & $21.02 \mathrm{c}-\mathrm{f}$ & $65.00 \mathrm{f}-\mathrm{j}$ & $60.00 \mathrm{ij}$ & $2.22 \mathrm{a}-\mathrm{d}$ & $4.60 b c$ \\
\hline FARO 66 & $6.00 \mathrm{a}-\mathrm{c}$ & $2.16 a-d$ & $22.65 a-d$ & $79.94 a-e$ & $112.17 \mathrm{a}-\mathrm{d}$ & $2.14 a-d$ & $4.92 b$ \\
\hline FARO 67 & $5.50 \mathrm{a}-\mathrm{e}$ & $1.78 \mathrm{c}-\mathrm{f}$ & $21.74 b-e$ & $61.83 \mathrm{~g}-\mathrm{j}$ & $115.50 \mathrm{a}-\mathrm{c}$ & $2.06 \mathrm{~b}-\mathrm{d}$ & $1.70 \mathrm{j}$ \\
\hline UPN 250 & $4.50 \mathrm{c}-\mathrm{h}$ & $1.55 \mathrm{c}-\mathrm{f}$ & $19.78 \mathrm{~d}-\mathrm{g}$ & $55.35 \mathrm{ij}$ & $90.67 \mathrm{c}-\mathrm{g}$ & $2.03 \mathrm{~b}-\mathrm{d}$ & $2.58 \mathrm{~g}-\mathrm{j}$ \\
\hline UPN 266 & $3.50 \mathrm{f}-\mathrm{i}$ & $1.84 \mathrm{~b}-\mathrm{e}$ & $19.72 \mathrm{~d}-\mathrm{g}$ & $52.33 \mathrm{j}$ & $107.33 \mathrm{a}-\mathrm{e}$ & $2.29 \mathrm{a}-\mathrm{d}$ & $2.07 \mathrm{~h}-\mathrm{j}$ \\
\hline UPN 295 & $3.83 \mathrm{e}-\mathrm{i}$ & $1.30 \mathrm{ef}$ & $17.37 \mathrm{e}-\mathrm{g}$ & $76.01 \mathrm{~b}-\mathrm{g}$ & $60.17 \mathrm{ij}$ & $2.06 \mathrm{~b}-\mathrm{d}$ & $2.31 \mathrm{~h}-\mathrm{j}$ \\
\hline UPN 318 & $4.83 b-f$ & $1.06 \mathrm{f}$ & $19.15 \mathrm{~d}-\mathrm{g}$ & $58.83 \mathrm{~h}-\mathrm{j}$ & $66.00 \mathrm{~g}-\mathrm{j}$ & $2.09 a-d$ & $4.60 \mathrm{bc}$ \\
\hline UPN 323 & $4.83 b-f$ & $1.56 \mathrm{c}-\mathrm{f}$ & $17.82 \mathrm{e}-\mathrm{g}$ & $80.58 \mathrm{a}-\mathrm{e}$ & $63.67 \mathrm{~g}-\mathrm{j}$ & $2.64 \mathrm{ab}$ & $4.12 b-f$ \\
\hline UPN 313 & $3.67 \mathrm{f}-\mathrm{i}$ & $1.21 \mathrm{ef}$ & $20.42 c-f$ & $59.52 \mathrm{~h}-\mathrm{j}$ & $52.33 \mathrm{j}$ & $2.23 a-d$ & $2.98 \mathrm{e}-\mathrm{i}$ \\
\hline UPN 253 & $4.17 \mathrm{~d}-\mathrm{i}$ & $1.95 \mathrm{~b}-\mathrm{e}$ & $25.75 \mathrm{ab}$ & $82.17 \mathrm{a}-\mathrm{d}$ & $98.67 b-f$ & $2.21 \mathrm{a}-\mathrm{d}$ & $4.42 b-d$ \\
\hline UPN 288 & $4.17 \mathrm{~d}-\mathrm{i}$ & $1.33 \mathrm{ef}$ & $21.87 \mathrm{~b}-\mathrm{e}$ & $60.17 \mathrm{~h}-\mathrm{j}$ & $80.83 \mathrm{e}-\mathrm{i}$ & $2.02 b-d$ & $1.79 \mathrm{ij}$ \\
\hline UPN 347 & $3.83 \mathrm{e}-\mathrm{i}$ & $1.51 \mathrm{c}-\mathrm{f}$ & $20.40 c-f$ & $67.67 \mathrm{~d}-\mathrm{i}$ & $78.00 \mathrm{f}-\mathrm{j}$ & $1.84 \mathrm{~cd}$ & $2.39 \mathrm{~h}-\mathrm{j}$ \\
\hline UPN 324 & $4.67 b-g$ & $1.60 \mathrm{c}-\mathrm{f}$ & $20.35 c-f$ & $61.00 \mathrm{~h}-\mathrm{j}$ & $88.17 \mathrm{c}-\mathrm{h}$ & $2.32 \mathrm{a}-\mathrm{d}$ & $4.57 \mathrm{bc}$ \\
\hline UPN 228 & $5.67 \mathrm{a}-\mathrm{d}$ & $1.67 \mathrm{c}-\mathrm{f}$ & $19.63 \mathrm{~d}-\mathrm{g}$ & $83.38 \mathrm{ab}$ & $120.83 \mathrm{ab}$ & $2.04 b-d$ & $4.95 b$ \\
\hline UPN 336 & $2.50 \mathrm{i}$ & $2.27 \mathrm{a}-\mathrm{c}$ & $18.27 \mathrm{~d}-\mathrm{g}$ & $68.33 c-i$ & $121.83 \mathrm{ab}$ & $2.19 \mathrm{a}-\mathrm{d}$ & $2.53 \mathrm{~g}-\mathrm{j}$ \\
\hline UPN 300 & $4.83 b-f$ & $1.49 \mathrm{~d}-\mathrm{f}$ & $19.62 \mathrm{~d}-\mathrm{g}$ & $60.25 \mathrm{~h}-\mathrm{j}$ & $94.83 b-f$ & $2.00 \mathrm{~b}-\mathrm{d}$ & $2.23 \mathrm{~h}-\mathrm{j}$ \\
\hline UPN 268 & $4.50 \mathrm{c}-\mathrm{h}$ & $1.83 \mathrm{c}-\mathrm{e}$ & $20.00 \mathrm{~d}-\mathrm{g}$ & $68.12 \mathrm{~d}-\mathrm{i}$ & $95.83 b-f$ & $2.03 b-d$ & $2.75 \mathrm{~g}-\mathrm{j}$ \\
\hline UPN 345 & $2.83 \mathrm{hi}$ & $1.23 \mathrm{ef}$ & $15.54 \mathrm{~g}$ & $79.50 \mathrm{a}-\mathrm{f}$ & $62.67 \mathrm{~h}-\mathrm{j}$ & $2.03 b-d$ & $2.92 \mathrm{f}-\mathrm{j}$ \\
\hline UPN 349 & $3.50 \mathrm{f}-\mathrm{i}$ & $1.73 c-f$ & $20.45 c-f$ & $66.33 \mathrm{e}-\mathrm{j}$ & $85.17 \mathrm{~d}-\mathrm{i}$ & $2.16 \mathrm{a}-\mathrm{d}$ & $3.27 \mathrm{~d}-\mathrm{h}$ \\
\hline UPN 257 & $3.00 \mathrm{~g}-\mathrm{i}$ & $1.33 \mathrm{ef}$ & $20.32 c-f$ & $72.97 b-h$ & $97.67 b-f$ & $1.90 \mathrm{~cd}$ & $2.74 \mathrm{~g}-\mathrm{j}$ \\
\hline Okporogwu & $4.67 \mathrm{~b}-\mathrm{g}$ & $1.27 \mathrm{ef}$ & $16.98 f g$ & $56.20 \mathrm{ij}$ & $64.00 \mathrm{~g}-\mathrm{j}$ & $1.75 \mathrm{~d}$ & $4.42 b-d$ \\
\hline UPIA 1 & $5.00 \mathrm{~b}-\mathrm{f}$ & $1.83 \mathrm{c}-\mathrm{e}$ & $20.78 c-f$ & $68.95 b-\mathrm{i}$ & $76.00 \mathrm{f}-\mathrm{j}$ & $2.52 \mathrm{a}-\mathrm{c}$ & $4.17 b-e$ \\
\hline UPIA 2 & $6.83 a$ & $2.70 \mathrm{a}$ & $26.79 a$ & $82.93 a-c$ & $108.17 \mathrm{a}-\mathrm{e}$ & $2.16 \mathrm{a}-\mathrm{d}$ & $7.44 \mathrm{a}$ \\
\hline S. E & 0.11 & 0.04 & 0.29 & 1.07 & 2.42 & 0.03 & 0.13 \\
\hline Grand Mean & 4.45 & 1.69 & 20.43 & 68.70 & 88.27 & 2.16 & 3.57 \\
\hline
\end{tabular}

Means that do not share a letter are significantly different. $\mathrm{PN}=$ Panicle number, $\mathrm{PW}=$ Panicle weight, $\mathrm{PL}=$ Panicle length, $\mathrm{SF}=$ Spikelet fertility, NOGPP $=$ Number of grains per panicle, $100 \mathrm{GW}=100$-grain weight, GYLD $=$ Grain yield per stand, $\mathrm{S} . \mathrm{E}=$ Standard error

Table 4: Pooled estimates of genetic variability and genetic parameters for 11 phenological and yield parameters in 25 rice varieties

\begin{tabular}{|c|c|c|c|c|c|c|c|c|c|}
\hline Characters & $\begin{array}{l}\text { Environme } \\
\text { ntal } \\
\text { variance } \\
(\text { Ve) } \\
\end{array}$ & $\begin{array}{l}\text { Genotypic } \\
\text { variance } \\
(\mathrm{Vg})\end{array}$ & $\begin{array}{l}\text { Genotype } \quad x \\
\text { environment } \\
\text { variance (Vge) }\end{array}$ & $\begin{array}{l}\text { Phenotypic } \\
\text { variance } \\
\text { (Vp) }\end{array}$ & $\begin{array}{l}\text { Heritability in } \\
\text { broad-sense } \\
\text { (HB) }\end{array}$ & $\begin{array}{l}\text { Genotypic } \\
\text { coefficient of } \\
\text { variation } \\
(\text { GCV) } \\
\end{array}$ & $\begin{array}{l}\text { Phenotypic } \\
\text { coefficient of } \\
\text { variation } \\
(\mathrm{PCV}) \\
\end{array}$ & $\begin{array}{l}\text { Genetic } \\
\text { advance } \\
\text { GA }\end{array}$ & $\begin{array}{l}\text { Genetic } \\
\text { advance } \\
\text { percentage of } \\
\text { mean GAM } \\
\end{array}$ \\
\hline $\begin{array}{l}\text { Plant height } \\
(\mathrm{cm})\end{array}$ & 84.73 & 30.44 & 7.17 & 122.35 & 24.88 & 7.35 & 14.73 & 5.67 & 7.55 \\
\hline $\begin{array}{l}\text { Leaf area } \\
\left(\mathrm{cm}^{2}\right) \\
\text { Days to } 50 \%\end{array}$ & 6.85 & 26.57 & 5.58 & 39.00 & 68.12 & 25.48 & 30.87 & 8.76 & 43.32 \\
\hline $\begin{array}{l}\text { flowering } \\
\text { Tiller }\end{array}$ & 6.53 & 16.26 & 21.85 & 44.64 & 36.42 & 4.48 & 7.42 & 5.01 & 5.57 \\
\hline $\begin{array}{l}\text { number } \\
\text { Panicle }\end{array}$ & 1.93 & 0.37 & 0.00 & 2.30 & 15.93 & 8.72 & 21.86 & 0.50 & 7.17 \\
\hline $\begin{array}{l}\text { number } \\
\text { Panicle }\end{array}$ & 0.60 & 1.05 & 0.00 & 1.65 & 63.41 & 22.98 & 28.86 & 1.68 & 37.70 \\
\hline $\begin{array}{l}\text { weight (g) } \\
\text { Panicle }\end{array}$ & 0.12 & 0.13 & 0.04 & 0.29 & 43.68 & 21.14 & 31.99 & 0.49 & 28.79 \\
\hline $\begin{array}{l}\text { length }(\mathrm{cm}) \\
\text { Spikelet }\end{array}$ & 4.34 & 4.96 & 1.65 & 10.95 & 45.31 & 10.90 & 16.20 & 3.09 & 15.12 \\
\hline $\begin{array}{l}\text { fertility } \\
\text { Number of } \\
\text { grains per }\end{array}$ & 45.54 & 88.15 & 41.80 & 175.49 & 50.23 & 13.67 & 19.28 & 13.71 & 19.95 \\
\hline $\begin{array}{l}\text { panicle } \\
100 \text {-grain }\end{array}$ & 159.20 & 283.20 & 408.23 & 850.63 & 33.29 & 19.06 & 33.04 & 20.00 & 22.66 \\
\hline $\begin{array}{ll}\text { weight }(\mathrm{g}) \\
\text { Grain } & \text { yield } \\
\text { per } & \text { stand }\end{array}$ & 0.10 & 0.03 & 0.01 & 0.14 & 22.04 & 8.23 & 17.54 & 0.17 & 7.96 \\
\hline ( $\mathrm{g} /$ stand $)$ & 0.32 & 1.40 & 0.79 & 2.51 & 55.87 & 33.21 & 44.43 & 1.82 & 51.13 \\
\hline
\end{tabular}

\section{Discussion}

The importance of variability studies in plant breeding and crop improvement cannot be overemphasized. The 
existence of genetic variability in a base population is germane to crop improvement as it is the basis on which plant breeding thrives. Hence, variability studies are needed as they are essential for kick-starting any efficient breeding programme. It is the presence of considerable genetic variability in the breeding material that will give room for better chances of developing desirable plant variety (Hosamani et al., 2018).

The observed variation among the means of the evaluated varieties shows the diverse nature of the genotypes. This variation is what plant breeders latch onto in any selection programme. Plant height and leaf area are very important parameters in rice which have been reported to affect panicle parameters, and consequently yield. Jun et al. (2007) had attributed the increase in panicle parameters in some rice cultivars evaluated to the increased plant height and large leaf area of such rice cultivars. They stated that cultivars with good leaf area and increased plant height utilize more efficiently the energy from the sun for photosynthesis. Also, Efisue et al. (2014) noted that nitrogen response and plant lodging behaviour of rice is partly determined by the height of the plant. Hence, such rice varieties with increased height and large leaf area have the potential for high yield as a result of effective utilization of nitrogen and sunlight which would increase the rate of photosynthesis. A positive influence of plant height and leaf area was similarly observed in this study as UPIA 2 which differed significantly from other varieties for plants height and leaf area, respectively, displayed superiority in yield.

Panicle parameters which include panicle number, panicle weight, panicle length, spikelet fertility, and number of grains per panicle, are important yield attributes of rice which are essential to be considered when evaluating individual varietal performance. Fageria and Baligar (2001) noted that grain yield in rice is a function of many panicle parameters. Similarly, Oko et al. (2012) emphasized that panicle parameters affect the overall rice yield and are often used as pointers to assess the performance of any particular rice cultivar. The high panicle numbers observed in some varieties such as in UPIA 2 (6.83) and FARO 44 (6.33) are pointers that they are good materials to be incorporated into a breeding programme for yield improvement as panicle numbers determine the numbers of spikelets in rice plant. Similarly, the consistency of varieties such as UPIA 2, FARO 44, UPN 228, UPN 336 and FARO 66 for high panicle weight, number of grains per panicle and spikelet fertility is an indication that they are potentially high yielding, which was also revealed by their yield data.

In this study, results from ANOVA showed significant $(\mathrm{P} \leq 0.05$ and $\mathrm{P} \leq 0.01)$ genotypic variation for majority of the parameters evaluated among the 25 rice varieties for each planting dates and for all parameters across the planting dates. This is an indication that considerable genetic variation exists among the varieties, which might be as a result of the differences in the genetic composition of the varieties. Such variations are beneficial to breeders for selecting better parental materials in a breeding programme. Similar results have been reported by Seyoun et al. (2012) and Kishore et al. (2015) in some rice genotypes and also by Konate et al. (2016) in 17 recombinant rice inbred lines and Tonegnikes et al. (2019) in some Korea rice germplasm. Effect of planting date and the interaction effect of variety by planting date were also significant $(\mathrm{P} \leq 0.05)$ for most of the parameters. This might be as a result of the effect of the prevailing climatic conditions in the two planting dates.

The phenotypic coefficient of variation (PCV) and genotypic coefficient of variation (GCV) values are very useful in crop improvement through selection (Johnson et al., 1955). These parameters are used for comparing the relative amount of phenotypic and genotypic variation observed in different characters. As observed in the study, the higher phenotypic variance $(\mathrm{Vp})$ and phenotypic coefficient of variation $(\mathrm{PCV})$ in relation to the corresponding genotypic variance $(\mathrm{Vg})$ and genotypic coefficient of variation $(\mathrm{GCV})$, respectively for all the parameters studied, is indicative the environment has a role to play in the expression of these parameters. Dutta et al. (2013), Singh et al. (2014), Tuhina-Khatun et al. (2015) and Konate et al. (2016) had reported similar results in rice. Also, the low to moderate GCV and PCV recorded for majority of the characters is a further proof that these characters were influenced by the environment, hence limiting the possibility for simple selection as their phenotypic expression would not be a good indicator of their genetic potential. However, selection maybe effective based on leaf area, panicle number, panicle weight, grain yield per stand and number of grains per panicle which had high GCV and PCV. Similar results of high GCV and PCV have been reported by Saha et al. (2019) (leaf area, number of grains per panicle and grain yield per plant), Singh and Verma (2018) (leaf area and number of grains per panicle) and Tuhina-Khatun et al. (2015) (grain yield per plant).

In quantitative genetics, and in particular, selective breeding, the concept of heritability is very important. The most important function of heritability estimates in genetic study of quantitative characters is its predictive role to indicate the dependability of the phenotypic value as a guide to breeding value (Falconer and Mackay, 1996; Al-Tabbal and Fraihat, 2012). Majority of the characters under study were found to have moderate heritability estimates which is at variance with the results reported by Seyoun et al., (2012) and Konate et al., (2016) in rice with higher estimates. Although, the authors only estimated heritability over a single planting date. The genotype by environment interaction (GEI) effect might be the reason for the observed variance, as GEI is a recognised source of variation that impedes heritability (Kang, 1997). Toker (2004) and Mudler and Bijma (2005) had emphasized the need to estimate heritability over pooled environments as it helps negate bias. They reiterated that although heritability estimates pooled over environments are often low in magnitude, they are very reliable in the prediction of genetic gain of characters in breeding programmes. 
Heritability estimates alone however does not reflect expected genetic gain. Heritability estimates are to be considered simultaneously with genetic advance. Singh and Marayanan (1993) reiterated that high values of genetic advance as percentage of mean (GAM) are indicative of additive gene effect whereas low values are indicative of non-additive gene effect. Hence, high $(>50)$ heritability estimate accompanied by high genetic advance in leaf area, panicle number, and grain yield per stand suggests that selection for these parameters might be more promising because they are controlled by additive gene action. Similar high heritability estimates coupled with high genetic advance had been reported by Kishore et al. (2015) in grain yield per plant and Singh and Verma (2018) in leaf area.

\section{Conclusion}

It could be concluded from this study that considerable amount of genetic variability exists among the studied rice varieties for grain yield and its components, which makes the rice varieties an option for selection as parent materials in breeding programs in this agro-ecological zone. The moderate broad sense heritability estimates obtained for majority of the parameters is an indication of the influence of the environment on the genetic potentials of the rice varieties hence, limiting the possibility of simple selection, though reliable because it is from pooled environment. This also justifies the essence of these varietal trial in Port Harcourt. Furthermore, high heritability accompanied by high genetic advance in leaf area, panicle number and grain yield per stand means that selection for these parameters will be promising being controlled by additive gene action.

\section{References}

Adhikari, B.N., Pokhrel, B.B., \& Shrestha, J. (2018). Evaluation and development of finger millet (Eleusinecoracana L.) genotypes for cultivation in high hills of Nepal. Farming and Management, 3(1), 37 46.

Balqees H. AL-Musawil and Mohammed A. AL-Anbari., 2019. Comparative study of new rice genotypes (oryza sativa 1.) introduced in middle of iraq. Biochem. Cell. Arch. Vol. 19, Supplement 1, pp. 2453-2456, 2019.

Dimkpa S. O. N., (2014). A genome wide association mapping and assessment of allelic variation in strigolactone synthesis genes involved in rice plant parasite interactions. PhD. Dissertation, University of Aberdeen, Scotland, United Kingdom.

Dimkpa, S.O.N., Lahari, Z., Shrestha, R., Douglas, A., Gheysen, G., Price, A. (2015). A genome-wide association study of a global rice panel reveals resistance in Oryza to root-knot nematodes. Journal of Experimental Botany Vol. 67 (4), 1191-1200.

Dutta, P., Dutta, P. N. \& Borua, P. K. (2013). Morphological Traits as Selection Indices in Rice: A statistical view. University Journal of Agriculture Resources 1(3), 85-96.

Efisue A.A., \& Igoma E.E. (2008). Screening Oryza Sativa L. for Salinity Tolerance During Vegetative Stage for the Coastal Region of Niger-Delta Nigeria. Journal of Plant Sciences 7(1), 21-26.

Efisue, A. A., Tongoona, P., Derera, J., Ubi B. E., \& Oselebe, H. O. (2009) Genetics of Morpho-Physiological Traits in Segregating Populations of Interspecific Hybrid Rice Under Stress and Non-Stress Conditions. Journal of Crop Improvement, 23:383-401.

Efisue, A. A., Umuna, B. C. \&Joseph, A. O. (2014). "Effects of yield components on yield potential of some lowland rice (Oryza sativa L.) in coastal region of Southern Nigeria," Journal of Plant Breeding and Crop Science. 6(9), 119-127.

Efisue, A., Tongoona, P., Derera, J., Langyintuo, A., Laing, M., \&Ubi, B., (2008). Farmers' perceptions on rice varieties in Sikasso Region of Mali and their implications forrice breeding. Journal of Agronomy and Crop Science 194, 393-400.

FAO (2004) Food and Agriculture Organization of the United Nations. Available at: availablein:http://faostat.fao.org/site/567/Deskto pDefault.aspx?PageID=567\#ancor.

Hosamani, M., Kuchanur, P. H., Mahiboobsa, M., Nadakarni, S. R. \& Honnappa. (2018). Genetic variability for yield and yield attributing traits in maize (Zea mays L.). Journal of Pharmacognosy and Phytochemistry. 7(3), 1964-1966.

Jun, M. A., Wen-bo, M. A., Dong-Feng, M., Shing-ming, Y. \& Qing-seng, Z. (2007). Characteristics of the rice plant with heavy panicle. Agricultural Science in China, 5(12): 911-918.

Kahani F. \& Hittalmani S. 2016. Identification of f2 and f3 Segregants of Fifteen Rice crosses suitable for cultivation under aerobic situation. Sabrao Journal of Breeding and Genetics 48 (2), 219-229.

Kishore, N. S., Srinivas, T., Nagabhushanam, U., Pallavi, M. \& Sameera, S. K. (2015). Genetic Variability, Correlation and Path Analysis for Yield and Yield Components in Promising Rice (Oryza sativa L.) Genotypes. SAARC Journal of Agriculture, 13(1), 99-108.

Konate, A. K., Zongo, A., Kam, H., Sanni, A. \& Audebert, A. (2016). Genetic variability and correlation analysis of rice (Oryza sativa L.) inbred lines based on agromorphological traits. African Journal of Agricultural Research, 11(35), 3340-3346. 
Kumar, A., Basu S., Venkategowda R., and Andy P. 2017. Mechanisms of drought tolerance in rice. Burleigh Dodds Science Publishing Limited: 131-63.

Mukesh, M., Vidyabhushan, J., Anand, K., Mankesh., K. \& Shweta, K. (2018) Correlation and path coefficient analysis in rice (Oryza sativa L.) genotypes for yield and it sattributing traits. Journal of Pharmacognosy and Phytochemistry 4, 285-290.

Oko, A. O., Ubi, B. E., \& Efisue, A. A. (2012). A Comparative Study on Local and Newly Introduced Rice Varieties in Ebonyi State of Nigeria based on Selected Agronomic Characteristics. International Journal of Agriculture and Forestry, 2(1), 11-17. http://doi.org/10.5923/j.ijaf.2012201.03.

Oluwaseyi A. B., Nehemmiah D., and Zuluqurineen S. B. (2016). Genetic Improvement of Rice in Nigeria for Enhanced Yeild and Grain Quality - A Review. Asian Research Journal of Agriculture 1(3): 1-18.

Saha, S. R., Hassan, L., Haque, M. A., Islam, M. M. \& Rasel, M. (2019). Genetic variability, heritability, correlation and path analyses of yield components in traditional rice (Oryza sativa L.) landraces. Journal of Bangladesh Agricultural University, 17(1), 26-32. https://doi.org/10.3329/jbau.v17i1.40659

Sathya R, Jebaraj S (2013). Heritability and genetic advance estimates from three rice line hybrids under aerobic condition. International Journal of Agricultural Science Resource, 3(3), 69-74

Seyoun, M., Alamerew, S. \& Bantte, K. (2012). Genetic Variability, Heritability, Correlation Coefficient and Path Analysis for Yield and Yield Related Traits in Upland Rice (Oryza sativa L.). Journal of Plant Sciences 7(1), 13-22.

Singh, A., Singh, A. K., Singh, V., Singh, N., Singh, V. N., Shamin, M., Vikram, P. \& Singh, S. (2014). Genetic variability among traits associated with grain yield of rice (Oryza sativa L.) exposed to drought at flowering stage. African Journal of Research 9(16), 1252.

Singh, K., Punia, M. S.,Singh, V.,\& Jagdale, V. (2017). Inter-Generation Correlation and Regression Analysis in F2 and F3 Generations of Wheat. International Journal of Pure and Applied. Bioscience, 5 (6), 809-816.

Tonegnikes, S., Efisue, A., Adetimirin, V., Shittu, A.\& Amegan, E. (2019). Evaluation of

Korea Rice Germplasm for Yield and Yield Components Adaptable to Nigeria Environmental Conditions. Journal of Plant Sciences 7(5), 106-116. http://doi.org/10.11648/j.jps.20190705.12.

Tuhina-Khatun, M., Hanafi, M. M., Yusop, M. R., Wong, M. Y., Salleh, F. M., \& Ferdous, J.

(2015). Genetic variation, heritability, and diversity analysis of upland rice (Oryza sativa L.) genotypes based on quantitative traits. BioMedical Research International, ID 290861.

Truong Thi Tu Anh 1, Tran Dang Khanh 2, Tran Dang Dat 3 and Tran Dang Xuan.

Identification of Phenotypic Variation and Genetic Diversity in Rice (Oryza sativa L.) Mutants. Agriculture 2018, 8,30 .

Ubi B. E., Efisue A. A. \& Oselebe O. H. (2011). Diversity of Drought Stress Tolerance

Response in Rice Cultivars and Breeding Lines at the Vegetative Stage, Journal of Agriculture, Biotechnology \& Ecology, 4(3), 70-89. 